\title{
Analisis Produksi Temulawak Sebagai Bahan Baku Jamu Di Balai Besar Penelitian Dan Pengembangan Tanaman Obat dan Obat Tradisional Tawangmangu
}

Penulis

Afiliasi

\section{Nurul Husniyati Listyana ${ }^{1 *}$, Meiviana Gina ${ }^{2}$}

\author{
${ }^{1}$ Balai Besar Penelitian dan Pengembangan Tanaman Obat dan Obat Tradisional \\ ${ }^{2}$ Fakultas Pertanian Universitas Sebelas Maret
}

\section{Diterima 25 Mei 2016 Direvisi 5 Desember 2016 Disetujui 9 Februari 2017}

\section{ABSTRAK}

Telah dilakukan penelitian mengenai analisis produksi temulawak sebagai bahan baku jamu di Balai Penelitian dan Pengembangan Tanaman Obat dan Obat Tradisional Tawangmangu. Temulawak merupakan tanaman obat yang banyak dibutuhkan oleh industri obat tradisional. Pada tahun 2003 kebutuhan simplisia temulawak menempati urutan pertama dilihat dari jumlah serapan ndustri obat tradisional. Penelitian ini dilaksanakan di Balai Besar Penelitian dan Pengembangan Tanaman Obat dan Obat Tradisional. Penelitian ini bertujuan untuk menganalisis kelayakan usaha produksi temulawak sebagai bahan baku obat tradisional. Penelitian ini menggunakan metode deskriptif, pengumpulan data dilakukan lewat teknik wawancara dan pengamatan di lapangan. Hasil penelitian menunjukkan bahwa usaha produksi temulawak layak untuk dikembangkan. Produksi temulawak lebih efisien jika temulawak berasal dari hasil panen kebun sendiri dibandingkan dengan membeli temulawak segar dari petani.

\section{PENDAHULUAN}

Indonesia merupakan negara yang kaya akan keanekaragaman hayati yang dapat digunakan sebagai obat untuk berbagai macam penyakit. Obat - obat yang berasal dari tanaman disebut juga obat herbal. Obat herbal ini sering digunakan karena memiliki efek samping yang minimal bahkan ada pula yang tidak ditemukan efek sampingnya. Obat herbal dianggap dan diharapkan dapat berperan dalam usaha-usaha pencegahan dan pengobatan penyakit, serta dalam peningkatan taraf kesehatan masyarakat.

Temulawak merupakan salah satu tanaman obat yang banyak manfaatnya dan termasuk tanaman yang dibutuhkan dalam jumlah besar dibanding tanaman obat lainnya. Temulawak merupakan tumbuhan asli Indonesia. Temulawak tumbuh di seluruh pulau Jawa, tumbuh liar di bawah naungan di hutan jati, di tanah yang kering dan di padang alang-alang, ditanam atau tumbuh liar di tegalan; tumbuh pada ketinggian tempat 5-1500 m di atas permukaan laut (Depkes RI, 1979; Depkes RI, 1989).

Temulawak mengandung minyak atsiri (sikloisoprenmirsen, p-tolilmetilkarbinol, kamfer), kurkumin, xantorizol, kurkuminoid, minyak atsiri dengan komponen
*Penulis korespondensi Nurul Husniyati Listyana Jl. Raya Lawu No. 11, Tawangmangu, Kalisoro, Karanganyar, Jawa Tengah Email : nurul.haydar@gmail.com 
$\alpha$-kurkumen, germakran, ar-turmeron, $\beta$-atlantanton, d-kamfor (Backer 1967; Hideji et al. 1985; Shin-Ichi et al, 1992; Jantan et al, 2004; Lin et al, 1995). Kegunaan utama rimpang temulawak (Curcuma xanthorrhiza Roxb.) adalah sebagai bahan baku obat, karena dapat merangsang sekresi empedu dan pankreas. Kebutuhan simplisia temulawak sebagai bahan baku obat tradisional di Jawa Tengah dan Jawa Timur tahun 2003 menduduki peringkat pertama dilihat dari jumlah serapan industri obat tradisional (Direktorat Budidaya Tanaman Sayuran dan Biofarmaka, 2006).

Tingginya permintaan temulawak untuk kebutuhan industri obat tradisional, membuka peluang bagi petani untuk mengembangkan lahan untuk budidaya temulawak. Selain dibutuhkan dalam bentuk basah/segar, temulawak juga dibutuhkan dalam bentuk kering/simplisia. Dalam penelitian akan dilakukan analisis perbandingan antara produksi simplisia temulawak yanag berasal dari hasil kebun sendiri dan berasal dari pembelian temulawak segar. Penelitian ini bertujuan untuk menganalisis kelayakan usaha produksi temulawak untuk bahan baku jamu di Balai Besar Penelitian dan Pengembangan Tanaman Obat dan Obat Tradisional.

\section{METODE}

Penelitian ini menggunakan metode deskriptif. Data diperoleh dari hasil wawancara dan pengamatan di lapang.

\section{Analisis Data}

Untuk menghitung kelayakan usaha produksi temulawak digunakan rumus sebagai berikut :

$$
\mathrm{R} / \mathrm{C} \text { ratio }=\frac{\text { total penerimaan }}{\text { total biaya }}
$$

Menurut Darsono (2008) R/C rasio merupakan metode analisis untuk mengukur kelayakan usaha dengan menggunakan rasio penerimaan (revenue) dan biaya (cost).
Sedangkan untuk menghitung apakah usahatani temulawak menguntungkan atau tidak digunakan rumus sebagai berikut :

$$
\mathrm{B} / \mathrm{C} \text { ratio }=\frac{\text { total pendapatan }}{\text { total biaya }}
$$

Benfit/Cost ratio adalah merupakan perbandingan antara total penerimaan dengan total biaya. Semakin besar B/C ratio maka akan semakin besar pula keuntungan yang diperoleh petani (Soekartawi, 2003).

Untuk menghitung nilai BEP dan ROI digunakan rumus sebagai berikut :

$$
\begin{gathered}
\text { BEP produksi }=\frac{\text { total biaya produksi }}{\text { harga jual produk }} \\
\text { BEP harga }=\frac{\text { total biaya produksi }}{\text { jumlah produk yang dihasilkan }} \\
\text { ROI }=\frac{\text { pendapatan }}{\text { total biaya produksi }} \times 100 \%
\end{gathered}
$$

\section{HASIL DAN PEMBAHASAN}

Analisis usaha dilakukan untuk mengetahui layak tidaknya suatu usaha yang dilakukan. Jika lahan milik B2P2TOOT tidak mampu memasok bahan segar, maka bahan segar dapat dibeli di petani lain. Berikut adalah perkiraan analisis usaha produksi simplisia temulawak sebagai bahan baku obat tradisional dalam sekali produksi di B2P2TOOT yang bahan segarnya berasal dari lahan milik sendiri dan dari petani lain:

\section{Penerimaan}

Penerimaan usaha merupakan hasil produksi dikali dengan harga jual. Tabel 1 menunjukkan hasil produksi usaha simplisia temulawak sebagai obat tradisional dalam sekali produksi adalah sebanyak 495 kg. Hasil produksi simplisia ini berasal dari bahan basah sebanyak $3960 \mathrm{~kg}$ yang kemudian mengalami penyusutan sekitar $1: 8$ setelah melewati proses pasca

Tabel 1. Penerimaan usaha produksi simplisia temulawak

\begin{tabular}{lcc}
\multicolumn{1}{c}{ Uraian } & Rata-rata per usaha & Satuan \\
\hline Hasil Produksi Simplisia & 495 & $\mathrm{Kg}$ \\
Harga Simplisia & 50.000 & $\mathrm{Rp} / \mathrm{kg}$ \\
\hline Total Penerimaan & $\mathbf{2 4 . 7 5 0 . 0 0 0}$ & $\mathbf{R p}$
\end{tabular}


panen. Hasil produksi simplisia ini memiliki harga jual Rp. 50.000,00 per kilogram sehingga total hasil penerimaan yang diterima adalah Rp. 24.750.000,00.

\section{Biaya Total Usaha}

Biaya total usaha merupakan jumlah keseluruhan biaya yang dikeluarkan untuk menjalankan suatu usaha. Biaya total usaha terdiri dari biaya tetap dan biaya variabel. Dalam menghitung jumlah biaya yang dikeluarkan kita juga harus memperhitungkan baya penyusutan suatu faktor produksi yang kita gunakan. Biaya penyusutan dirumuskan sebagai berikut :
Penyusutan $=\frac{\text { Jumlah Harga Beli }- \text { Jumlah Nilai Sisa }}{\text { Umur Ekonomis }}$

Biaya tetap adalah biaya yang dikeluarkan selama produksi yang besarnya tidak dipengaruhi oleh banyaknya produksi yang dihasilkan. Tabel 2 menunjukkan jika bahan segar berasal dari lahan B2P2TOOT, maka total biaya tetap usaha produksi simplisia temulawak sebagai bahan baku obat tradisional yang harus dikeluarkan adalah sebesar Rp.456.400,00.

Tabel 2. Biaya tetap usaha produksi simplisia temulawak dari lahan B2P2TOOT

\begin{tabular}{llrrrrrrr}
\hline No & \multicolumn{1}{c}{ Uraian } & $\begin{array}{c}\text { Jumlah } \\
\text { (Unit) }\end{array}$ & $\begin{array}{c}\text { Harga } \\
\text { Beli (Rp) }\end{array}$ & $\begin{array}{c}\text { Jumlah } \\
\text { Harga Beli } \\
\text { (Rp) }\end{array}$ & $\begin{array}{c}\text { Umur } \\
\text { Ekonomis } \\
\text { (Tahun) }\end{array}$ & $\begin{array}{c}\text { Nilai } \\
\text { Sisa } \\
\text { (Rp) }\end{array}$ & $\begin{array}{c}\text { Jumlah } \\
\text { Nilai Sisa }\end{array}$ & $\begin{array}{c}\text { Jumlah Biaya } \\
\text { Penyusutan }\end{array}$ \\
\hline 1. & Cangkul & 6 & 50.000 & 300.000 & 1 & 15.000 & 90.000 & 210.000 \\
2. & Gembor & 3 & 35.000 & 105.000 & 3 & 0 & 0 & 35.000 \\
3. & Ember & 3 & 8.000 & 24.000 & 1 & 0 & 0 & 24.000 \\
4. & Sabit & 6 & 25.000 & 150.000 & 1 & 5.000 & 30.000 & 120.000 \\
5. & Hand Sprayer & & & & & & & \\
& $\begin{array}{l}\text { a. 14 L } \\
\text { b. 2 L }\end{array}$ & 1 & 400.000 & 400.000 & 5 & 100.000 & 100.000 & 60.000 \\
\hline & Total Biaya Tetap & 40.000 & 40.000 & 5 & 3.000 & 3.000 & 7.400 \\
\hline
\end{tabular}

Sumber: Data Primer

Tabel 3. Biaya variabel usaha produksi simplisia temulawak dari lahan B2P2TOOT

\begin{tabular}{|c|c|c|c|c|c|}
\hline No & Uraian & Volume & Satuan & $\begin{array}{l}\text { Biaya Satuan } \\
\text { (Rp) }\end{array}$ & $\begin{array}{c}\text { Jumlah Biaya } \\
(\mathbf{R p})\end{array}$ \\
\hline 1. & Bibit & 40 & $\mathrm{Kg}$ & 4.500 & 180.000 \\
\hline 2. & Pupuk kandang & 10.000 & $\mathrm{Kg}$ & 150 & 1.500 .000 \\
\hline 3. & Pestisida biologis & 1 & Botol & 40.000 & 40.000 \\
\hline 3. & Karung & 70 & Lembar & 1.500 & 10.500 \\
\hline 4. & Bensin & 10 & Liter & 7.050 & 70.500 \\
\hline 5. & Plastik Kemasan & 400 & Lembar & 500 & 200.000 \\
\hline \multirow[t]{5}{*}{6.} & Penggunaan Mesin & & & & \\
\hline & a. Mesin pencucian rimpang & 6,67 & kwh & 1.352 & 9.018 \\
\hline & b. Mesin perajang rimpang & 4,15 & kwh & 1.352 & 5.611 \\
\hline & c. Oven room & 1.152 & kwh & 1.352 & 1.557 .504 \\
\hline & d. Mesin pengemasan & 12,4 & kwh & 1.352 & 16.765 \\
\hline \multirow[t]{7}{*}{7.} & Tenaga Kerja & & & & \\
\hline & a. Pengolahan lahan dan & 18,75 & HOK & 70.000 & 1.312 .500 \\
\hline & penanaman & 9 & HOK & 70.000 & 630.000 \\
\hline & b. Perawatan & 37,5 & HOK & 70.000 & 2.625 .000 \\
\hline & c. Panen & 1,875 & HOK & 70.000 & 131.250 \\
\hline & d. Sortasi basah - Perajangan & 1,25 & HOK & 70.000 & 87.500 \\
\hline & $\begin{array}{l}\text { e. Pengeringan Sinar Matahari } \\
\text { f. Pengovenan - Pengemasan }\end{array}$ & 1,875 & HOK & 70.000 & 131.250 \\
\hline
\end{tabular}

Sumber: Data Primer 
Biaya variabel adalah biaya yang dikeluarkan selama proses produksi yang besarnya dipengaruhi oleh banyaknya produksi yang dihasilkan. Besarnya biaya upah tenaga kerja merupakan salah satu komponen biaya yang masuk ke dalam biaya variabel. Dalam menghitung upah tenaga kerja terlebih dahulu harus dihitung Hari Orang Kerja (HOK) yang dirumuskan sebagai berikut :

$$
\text { HOK }=\frac{\text { Jumlah Tenaga Kerja } x \text { Jumlah Hari Kerja }}{\text { Jam Kerja }}
$$

Tabel 3 menunjukkan jika bahan segar berasal dari lahan B2Р2TOOT, maka total biaya variabel usaha produksi simplisia temulawak yang harus dikeluarkan untuk sekali produksi adalah sebesar Rp. 8.507.398,00. Sedangkan Tabel 4 menunjukkan jika bahan segar berasal dari petani lain, maka total biaya variabel usaha produksi simplisia temulawak yang harus dikeluarkan untuk sekali produksi adalah sebesar Rp. 19.958.898,00.

Biaya total merupakan penjumlahan dari total biaya tetap dan total biaya variabel. Tabel 5 menunjukkan jika bahan segar berasal dari lahan B2P2TOOT, maka total biaya produksi yang harus dikeluarkan untuk sekali produksi adalah sebesar
Rp.8.963.798,00. Sedangkan jika bahan segar berasal dari petani lain, maka total biaya produksi yang harus dikeluarkan untuk sekali produksi adalah sebesar Rp.19.958.898,00.

\section{Pendapatan Usahatani}

Pendapatan merupakan selisih antara total penerimaan dengan total biaya produksi yang dikeluarkan (Soekartawi 2006). Tabel 6 menunjukkan jika bahan segar berasal dari lahan B2P2TOOT, maka jumlah pendapatan usaha produksi simplisia temulawak sebagai bahan baku obat tradisional dalam sekali produksi adalah Rp.15.786.202,00. Sedangkan jika bahan segar berasal dari petani lain, maka jumlah pendapatan usaha produksi simplisia temulawak sebagai bahan baku obat tradisional dalam sekali produksi adalah Rp.4.791.102,00.

\section{BEP (Break Event Point)}

BEP produksi merupakan perbandingan antara total biaya produksi dengan harga jual produk, sedangkan BEP harga merupakan perbandingan antara total biaya produksi dengan hasil produksi yang dihasilkan. Berdasarkan Tabel 7 jika bahan segar berasal dari lahan B2P2TOOT, maka dapat diketahui bahwa nilai BEP produksi adalah sebesar 179 , artinya usaha produksi simplisia temulawak sebagai bahan

Tabel 4. Biaya variabel usaha produksi simplisia temulawak berasal dari petani lain

\begin{tabular}{|c|c|c|c|c|c|}
\hline NO & $\begin{array}{r}\text { Uraian } \\
\end{array}$ & Volume & Satuan & Biaya Satuan (Rp) & Jumlah Biaya (Rp) \\
\hline 1. & Bahan Basah Simplisia & 3960 & $\mathrm{Kg}$ & 4.500 & 17.820 .000 \\
\hline 2. & Plastik Kemasan & 400 & Lembar & 500 & 200.000 \\
\hline \multirow[t]{5}{*}{3.} & Penggunaan Mesin & & & & \\
\hline & a. Mesin pencucian rimpang & 6,67 & kwh & 1.352 & 9.018 \\
\hline & b. Mesin perajang rimpang & 4,15 & kwh & 1.352 & 5.611 \\
\hline & c. Oven room & 1.152 & kwh & 1.352 & 1.557 .504 \\
\hline & d. Mesin pengemasan & 12,4 & kwh & 1.352 & 16.765 \\
\hline \multirow[t]{5}{*}{4.} & Tenaga Kerja & & & & \\
\hline & a. Sortasi basah - Perajangan & 1,875 & HOK & 70.000 & 131.250 \\
\hline & b. Pengeringan Sinar Matahari & 1,25 & HOK & 70.000 & 87.500 \\
\hline & c. Pengovenan - Pengemasan & 1,875 & HOK & 70.000 & 131.250 \\
\hline & Total Biaya Variabel & & & & 19.958 .898 \\
\hline
\end{tabular}

Sumber : Data Primer

Tabel 5. Biaya total usaha produksi simplisia temulawak

\begin{tabular}{lcc}
\multicolumn{1}{c}{ Uraian } & Lahan B2P2TOOT (Rp) & Petani Lain (Rp) \\
\hline Biaya Tetap & 456.400 & - \\
Biaya Variabel & 8.507 .398 & 19.958 .898 \\
\hline Total Biaya Produksi & $\mathbf{8 . 9 6 3 . 7 9 8}$ & $\mathbf{1 9 . 9 5 8 . 8 9 8}$ \\
\hline Sumber $:$ Da & & \\
\hline
\end{tabular}

Sumber : Data Primer

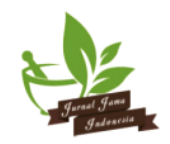


Tabel 6. Pendapatan usaha produksi simplisia temulawak

\begin{tabular}{lcr}
\hline \multicolumn{1}{c}{ Uraian } & $\begin{array}{c}\text { Lahan B2P2TOOT } \\
\text { (Rp) }\end{array}$ & Petani Lain (Rp) \\
\hline Total Penerimaan & 24.750 .000 & 24.750 .000 \\
Total Biaya Produksi & 8.963 .798 & 19.958 .898 \\
Jumlah Pendapatan & 15.786 .202 & 4.791 .102 \\
\hline
\end{tabular}

Sumber : Data Primer

Tabel 7. Hasil analisis BEP pada usaha produksi simplisia temulawak

\begin{tabular}{lrr} 
& Uraian & \multicolumn{1}{c}{ Lahan } \\
B2P2TOOT & \multicolumn{1}{c}{ Petani Lain } \\
\hline Total Biaya Produksi & 8.963 .798 & 19.958 .898 \\
Harga & 50.000 & 50.000 \\
Hasil Produksi & 495 & 495 \\
BEP Produksi & 179 & 399 \\
BEP Harga & 18.109 & 40.321 \\
\hline
\end{tabular}

Sumber : Data Primer

baku obat tradisional tidak untung dan tidak rugi pada level output $179 \mathrm{~kg}$ dan akan mendapatkan keuntungan jika output lebih besar dari $179 \mathrm{~kg}$. Usaha produksi simplisia temulawak sebagai bahan baku obat tradisional ini mendapatkan keuntungan dari selisih hasil produksi yang dihasilkan yaitu sejumlah $316 \mathrm{~kg}$ dan untuk BEP harga sebesar 18.109, artinya untuk usaha produksi simplisia temulawak sebagai bahan baku obat tradisional ini tidak rugi dan tidak untung pada harga Rp.18.109,00. Keuntungan akan diperoleh jika harga jual lebih besar dari Rp. Rp.18.109,00/kg. Usaha produksi simplisia temulawak sebagai bahan baku obat tradisional ini mendapatkan keuntungan dari selisih hasil harga jual produk yaitu sejumlah Rp.31.891,00 / kg.

Nilai BEP produksi jika bahan segar berasal dari petani lain adalah sebesar 399, artinya usaha produksi simplisia temulawak sebagai bahan baku obat tradisional tidak untung dan tidak rugi pada level output $399 \mathrm{~kg}$ dan akan mendapatkan keuntungan jika output lebih besar dari $399 \mathrm{~kg}$. Usaha produksi simplisia temulawak sebagai bahan baku obat tradisional ini mendapatkan keuntungan dari selisih hasil produksi yang dihasilkan yaitu sejumlah $99 \mathrm{~kg}$ dan untuk BEP harga sebesar 40.321, artinya untuk usaha produksi simplisia temulawak sebagai bahan baku obat tradisional ini tidak rugi dan tidak untung pada harga Rp.40.321,00. Keuntungan akan diperoleh jika harga jual lebih besar dari Rp. Rp.40.321,00/kg. Usaha produksi simplisia temulawak sebagai bahan baku obat tradisional ini mendapatkan keuntungan dari selisih hasil harga jual produk yaitu sejumlah Rp.9.679,00 /kg.
Jadi untuk usaha produksi simplisia temulawak sebagai bahan baku obat tradisional jika bahan segar berasal dari B2P2TOOT, maka diperoleh keuntungan BEP produksi sebesar $316 \mathrm{~kg}$ dan BEP harga sebesar Rp.31.891,00/kg. Sedangkan jika bahan segar berasal dari petani lain, maka diperoleh keuntungan BEP produksi sebesar $99 \mathrm{~kg}$ dan BEP harga sebesar Rp.9.679,00/kg.

\section{R/C Ratio (Revenue/Cost Ratio)}

Nilai R/C Ratio adalah perbandingan antara penerimaan dengan biaya produksi. Berdasarkan Tabel 8 menunjukkan jika bahan segar berasal dari lahan B2P2TOOT, maka nilai R/C Ratio yang diperoleh adalah sebesar 2,76. Sedangkan jika bahan segar berasal dari petani lain, maka nilai R/C Ratio yang diperoleh adalah sebesar 1,24. Karena nilai R/C Ratio lebih dari 1 maka menunjukkan bahwa kondisi usaha produksi simplisia temulawak sebagai bahan baku obat tradisional ini layak untuk diusahakan.

\section{Analisis B/C Ratio (Benefit/Cost Ratio)}

Nilai B/C Ratio adalah perbandingan antara pendapatan dengan biaya produksi. Berdasarkan tabel 9 menunjukkan jika bahan segar berasal dari lahan B2P2TOOT, maka nilai B/C Ratio yang diperoleh adalah sebesar 1,76. Karena nilai B/C Ratio 1,76 sehingga menunjukkan lebih dari 1 , maka kondisi usaha produksi simplisia temulawak sebagai bahan baku obat tradisional ini menguntungkan untuk dijalankan.

Sedangkan jika bahan segar berasal dari petani lain, maka nilai B/C Ratio yang diperoleh adalah 
Tabel 8. Hasil analisis $\mathrm{R} / \mathrm{C}$ ratio pada usaha produksi simplisia temulawak

\begin{tabular}{lrr}
\multicolumn{1}{c}{ Uraian } & Lahan B2P2TOOT & \multicolumn{1}{c}{ Petani Lain } \\
\hline Total Penerimaan & 24.750 .000 & 24.750 .000 \\
Total Biaya Produksi & 8.963 .798 & 19.958 .898 \\
R/C Ratio & 2,76 & 1,24 \\
\hline
\end{tabular}

Sumber : Data Primer

Tabel 9. Hasil analisis $\mathrm{B} / \mathrm{C}$ ratio pada usaha produksi simplisia temulawak

\begin{tabular}{lrr}
\multicolumn{1}{c}{ Uraian } & Lahan B2P2TOOT & Petani Lain \\
\hline Total Pendapatan & 15.786 .202 & 4.791 .102 \\
Total Biaya Produksi & 8.963 .798 & 19.958 .898 \\
B/C Ratio & 1,76 & 0,24 \\
\hline
\end{tabular}

Sumber : Data Primer

sebesar 0,24. Karena nilai B/C Ratio 0,24 sehingga menunjukkan kurang dari 1, maka kondisi usaha produksi simplisia temulawak sebagai bahan baku obat tradisional ini kurang menguntungkan untuk dijalankan.

\section{ROI (Return On Investment)}

$$
\begin{aligned}
\text { ROI dari lahan sendiri } & =\frac{\text { Pendapatan }}{\text { Total Biaya Produksi }} \times 100 \% \\
& =\frac{15.786 .202}{8.963 .798} \times 100 \% \\
& =176,11 \%
\end{aligned}
$$

$$
\begin{aligned}
\text { ROI dari petani lain } & =\frac{\text { Pendapatan }}{\text { Total Biaya Produksi }} \times 100 \% \\
& =\frac{4.791 .102}{19.958 .898} \times 100 \% \\
& =24 \%
\end{aligned}
$$

Analisis Tingkat Efisiensi Penggunaan Modal atau Return on Investment (ROI) adalah analisis untuk mengetahui keuntungan usaha berkaitan dengan modal yang dikeluarkan. Jika bahan segar berasal dari lahan B2P2TOOT, maka nilai ROI yang diperoleh adalah $176,11 \%$. Hal ini menggambarkan bahwa dari Rp 100,00 modal yang digunakan akan diperoleh keuntungan sebesar $176,11 \%$.

Sedangkan jika bahan segar berasal dari petani lain, maka nilai ROI yang diperoleh adalah $24 \%$. Hal ini menggambarkan bahwa dari Rp 100,00 modal yang digunakan akan diperoleh keuntungan sebesar $24 \%$. Nilai ROI yang tinggi menunjukkan usaha produksi simplisia temulawak sebagai bahan baku obat tradisional ini sangat efisien.

Berdasarkan analisis diatas maka dapat dilihat jika bahan segar dari lahan B2P2TOOT, maka diperoleh pendapatan usaha Rp.15.786.202,00 yang jauh lebih besar daripada pendapatan usaha Rp.4.791.102,00 jika bahan segar berasal dari petani lain. Hal ini dipengaruhi karena total biaya usaha yang dikeluarkan jika bahan segar dari lahan B2P2TOOT sebesar Rp.8.963.798,00 lebih kecil daripada jika bahan segar dari petani lain yaitu sebesar Rp.19.958.898,00. Jika bahan segar dari lahan B2P2TOOT maka keuntungan BEP lebih besar daripada jika bahan segar dari petani lain, yaitu jika bahan segar berasal dari B2P2TOOT, maka diperoleh keuntungan BEP produksi sebesar $316 \mathrm{~kg}$ dan BEP harga sebesar Rp.31.891,00/kg. Sedangkan jika bahan segar berasal dari petani lain, maka diperoleh keuntungan BEP produksi sebesar $99 \mathrm{~kg}$ dan BEP harga sebesar Rp.9.679,00/kg. Dilihat dari nilai R/C Ratio keduanya memiliki nilai lebih dari 1 maka menunjukkan bahwa kondisi usaha produksi simplisia temulawak sebagai bahan baku obat tradisional ini layak untuk diusahakan. Jika dilihat dari B/C Ratio usaha produksi simplisia temulawak sebagai bahan baku obat tradisional ini lebih menguntungkan jika bahan segar berasal dari lahan B2P2TOOT daripada jika bahan segar berasal dari petani lain. Sedangkan jika dilihat dari ROI usaha produksi simplisia temulawak sebagai bahan baku obat tradisional ini lebih efisien jika bahan segar berasal dari lahan B2P2TOOT daripada jika bahan segar berasal dari petani lain, hal ini terjadi karena nilai ROI jika bahan segar dari lahan B2P2TOOT 176,11\% lebih besar dari jika bahan segar dari petani lain $24 \%$. Tingginya nilai ROI jika bahan segar berasal dari lahan

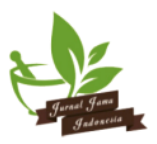


B2P2TO2T disebabkan karena nilai total biaya produksi yang jauh lebih rendah dibandingkan jika bahan segar berasal dari petani. Tingginya biaya produksi jika bahan segar berasal dari petani disebabkan tingginya biaya yang dikeluarkan untuk pembelian bahan segar dari petani. Nilai ROI yang tinggi menunjukkan usaha produksi simplisia temulawak sebagai bahan baku obat tradisional ini sangat efisien.

\section{KESIMPULAN}

Dari hasil di atas dapat disimpulkan bahwa pendapatan, kelayakan, keuntungan dan efisiensi lebih besar jika bahan segar dari lahan B2P2TOOT daripada jika bahan segar dari petani lain.

\section{DAFTAR PUSTAKA}

Backer CA, van den Brink RCB. 1965. Flora of Java (Spermatophytes Only). Vol. 3. Netherlands (NL): Noordhoff, Groningen.

Darsono. 2008. Hubungan Perceived Service Quality dan Loyalitas: Peran Trust dan Satisfaction sebagai Mediator. The 2 nd National Conference UKWMS. Surabaya (ID):

Departemen Kesehatan RI. 1979. Materia Medika Vol 3. Departemen Kesehatan RI. Jakarta.

Departemen Kesehatan RI. 1989. Vademekum Bahan Obat Alam. Departemen Kesehatan RI. Jakarta.

Direktorat Budidaya Tanaman Sayuran dan Biofarmaka. 2006. Profil Sentra Produksi Temulawak
(Curcuma xanthorrhiza Roxb). Direktorat Jenderal Hortikultura Departemen Pertanian.

Hideji I, Fusayoshi H, Kazuko F, Koichi T. 1985. Studies on The Antitumor Bisabolane Sesquiterpenoids Isolated from Curcuma xanthorrhiza. Chemical and Pharmaceutical Bulletin. 33(8): 3488-3492.

Shin-Ichi U, Ichiro Y, Koichi T, Hideji I. 1992. Terpenoids and Curcuminoids of The Rhizoma of Curcuma xanthorrhiza Roxb. Journal of the Pharmaceutical Society of Japan. 112(11): 817-823.

Jantan I, Pisar M, Sirat HM, Basar N, Jamil S, Ali RM, Jalil J. 2004. Inhibitory Effects of Compounds from Zingiberaceae Species on Platelet Activating Factor Receptor Binding. Phytotherapy Research. 18(12): 1005-1007.

Lin SC, Lin CC, Lin YH, Supriyatna S, Teng CW. 1995. Protective and Therapeutic Effects of Curcuma xanthorrhiza on Hepatotoxin-Induced Liver Damage. The American Journal of Chinese Medicine. 22(3-4): 243-254.

Pasar $\quad$ Fitofarmaka. 2007. http://bisnisfarmasi.wordpress.com. Diakses tanggal 22 November 2015.

Soekartawi. 2003. Teori Ekonomi Produksi. Jakarta (ID): Raja Grafindo Persada.

Soekartawi. 2006. Analisis Usahatani. Jakarta (ID): Universitas Indonesia Press. 